\title{
Anaplastic Malignant Neoplasm
}

National Cancer Institute

\section{Source}

National Cancer Institute. Anaplastic Malignant Neoplasm. NCI Thesaurus. Code C36025.

A malignant neoplasm characterized by the presence of poorly differentiated, often large neoplastic cells with bizarre morphologic characteristics, associated with high mitotic activity and necrotic changes. 